\title{
PERANAN PENDIDIKAN DALAM \\ MENGHINDARI PERGAULAN BEBAS ANAK USIA \\ REMAJA
}

\section{Sitti Nadirah}

\begin{abstract}
The promiscuity of juvenile delinquency is increasingly showing a very alarming increase. This paper examines the role of education in avoiding the promiscuity of adolescent children. With education it will create the formation of character. With the character of teenage children will "lead" themselves to do something right and not do something that is not true. This character becomes the determinant of whether adolescents are able or not to adjust to the diversity of situations that it faces, especially to avoid promiscuity. In addition to the realization of Gender-based education, women can earn nonloyal equality. Which in the long term can improve the protection, service and welfare of vulnerable women as the most disadvantaged party in free sex among adolescents.
\end{abstract}

\section{PENDAHULUAN}

Pergaulan bebas anak usia remaja pada era milenial masih menjadi polemik. Era milenial berjalan semakin cepat seiring dengan diikutinya peningkatan kemajuan teknologi yang memberikan nilai tambah dengan mudahnya mengakses segala informasi, hal ini memiliki dampak terhadap pola kehidupan masyarakat dari berbagai kalangan terutama anak usia remaja. Masa remaja merupakan masa peralihan dari masa kanak remaja-kanak remaja menuju masa dewasa. Dimana pada masa ini remaja seharusnya mulai belajar memikul tanggung jawab sebagai seorang remaja yang mampu berpikir dan bertindak sesuai dengan norma yang berlaku di masyarakat. Namun dengan adanya arus modernisasi pada era ini 
memberikan kemudahan bagi remaja untuk mengakses segala informasi dan seluk beluk mengenai hal-hal yang berbau dengan pergaulan bebas.

Keluarga yang pada dasarnya mempunyai peranan untuk membentuk perkembangan, kepribadian dan sebagai pengontrol bagi anak remajanya untuk dapat memberikan batasan-batasan dalam menjalani kehidupan sosial serta tempat pendidikan bagi remaja mulai semakin terkikis dengan masuknya era modernisasi. Dengan kurang tanggapnya pada diri orang tua mengenai pentingnya aturanaturan bagi remajanya, mengakibatkan remaja merasa bebas untuk menerima segala informasi yang didapat dari luar baik hal tersebut mengarahkan ke pergaulan bebas seperti melakukan seks bebas. Dengan ditunjang adanya pendukung seperti internet, tayangantayangan yang menjurus pada seks bebas dan banyaknya video porno yang beredar semakin meyakinkan remaja untuk meniru hal tersebut.

Dalam rentang waktu kurang dari dasawarsa terakhir, Pergaulan bebas yang merupakan kenakalan remaja semakin menunjukkan peningkatan yang sangat memprihatinkan. Diantara berbagai macam pergaulan bebas adalah seks bebas, kasus tawuran dan pecandu alkohol. Adapun Seks bebas yang dilakukan oleh remaja bisa dikatakan bukanlah suatu kenakalan lagi dari pergaulan bebas, melainkan suatu hal yang dianggap wajar dan telah menjadi kebiasaan.Tindakan seksual dikalangan remaja disatu sisi merupakan tuntutan dari dalam diri, mengingat usia remaja sudah pada tingkat kematangan seksual. Tetapi disisi lain hal itu juga akan berpengaruh pada proses pembelajaran sosial dan akademik bagi remaja dalam menempuh pendidikannya. Karena itu kajian ini akan menguraikan peranan pendidikan untuk menghindari pergaulan bebas pada anak usia remaja. 


\section{PEMBAHASAN}

\section{Penyebab Pergaulan Bebas}

Pergaulan bebas adalah salah satu bentuk prilaku menyimpang yang mana "bebas" yang dimaksud adalah melewati batas normanorma. ${ }^{1}$ Dari pengertian di atas dapat dipahami bahwa pergaulan bebas adalah prilaku manusia yang menyimpang yang melanggar norma-norma agama dan tidak ada batasannya. Pergaulan bebas dan dampak negatifnya ditinjau dari pendidikan Islam adalahtatacara pergaulan antara manusia dengan sesama manusia terutama dengan lawan jenisnya yang mengarah kepada pelaksanaan hubungan seks di luar nikah yangmempunyai konsekwensi destruksif, dan juga bertentangan dengan nilai-nilai yang terkandung dalam pendidikan Islam.

Dalam teori patologi sosial sejarah mencatat tentang masyarakat modern yang serba kompleks, sebagai produk dari kemajuan teknologi, mekanisasi, industrialisasi, dan urbanisasi, dll. Hal ini disamping mampu memberikan berbagai alternativ kemudahan bagi kehidupan manusia juga dapat menimbulkan Kesulitan mengadakan adaptasi dan adjustment menyebabkan kebingungan, kecemasan, dan konflik-konflik. Baik yang bersifat internal dalam batinnya sendiri maupun bersifat terbuka atau eksternalnya sehingga manusiacenderung banyak melakukan pola tingkah laku yang menyimpang dari pola yang umum dan banyak melakukan sesuatu apapun demi kepentingannya sendiri bahkan masyarakat cenderung merugikan orang lain. Hal ini sebagai pertautan tali yang melahirkan apa yang dinamakan dengan patologi sosial.

${ }^{1}$ Yusuf Abdullah, Bahaya Pergaulan Bebas(Jakarta : Media Dakwah ,1990), h. 142 
Patologi sosial adalah ilmu tentang gejala-gejala sosial yang dianggap "sakit" yang disebabkan oleh faktor-faktor social. Jadi ilmu tentang "penyakit masyarakat". Maka penyakit masyarakat itu adalah segenap tingkah laku manusia yang dianggap tidak sesuai, melanggar norma-norma umum dan adat istiadat, atau tidak integrasinya dengan tingkah laku umum.2

Pergaulan bebas adalah salah satu bentuk perilaku menyimpang, yang mana "bebas" yang dimaksud adalah melewati batas-batas norma agama yang ada. Masalah pergaulan bebas ini sering kita dengar baik di lingkungan maupun dari media massa. Remaja adalah individu labil yang emosinya rentan tidak terkontrol oleh pengendalian diri yang benar. Masalah keluarga, kekecewaan, pengetahuan yang minim,dan ajakan teman-teman yang bergaul bebas membuat makin berkurangnya potensi generasi muda Indonesia dalam kemajuan agama dan bangsa.

Pergaulan bebas adalah salah satu kebutuhan hidup dari makhluk manusia sebab manusia adalah makhluk sosial yang dalam kesehariannya membutuhkan orang lain, dan hubungan antar manusia dibina melalui suatu pergaulan (interpersonal relationship). Pergaulan juga adalah HAM setiap individu dan itu harus dibebaskan, sehingga setiap manusia tidak boleh dibatasi dalam pergaulan, apalagi dengan melakukan diskriminasi, sebab hal itu melanggar HAM. Jadi pergaulan antar manusia harusnya bebas, tetapi tetap mematuhi norma hukum, norma agama, norma budaya, serta norma bermasyarakat. Jadi, kalau secara medis kalau pergaulan bebas namun teratur atau terbatasi aturan-aturan dan norma-norma hidup manusia tentunya tidak akan menimbulkan ekses-ekses seperti saat ini. Di antara ciri-ciri dari pergaulan bebas adalah sebagai berikut:

\footnotetext{
${ }^{2}$ Kartini Kartono, Patologi social(PT. RajaGrafindo Persada:Jakarta, 2005), h.4
} 
a. Penghamburan harta untuk memenuhi keinginan sex bebasnya

b. Upaya mendapatkan harta dan uang dengan menghalalkan segala cara termasuk dari jalan yang haram dan keji.

c. Menimbulkan perilaku munafik dalam masyarakat

d. Rasa ingin tahu yang besar

e. Rasa ingin mencoba dan merasakan

f. Terjadi perubahan-perubahan emosi, pikiran, lingkungan pergaulan dan tanggung jawab yang dihadapi.

g. Mudah mengalami kegelisahan, tidak sabar, emosional, selalu ingin melawan, rasa malas, perubahan dalam keinginan, ingin menunjukkan eksistensi dan kebanggaan diri serta selalu ingin mencoba dalam banyak hal.

h. Kesukaran yang dialami timbul akibat konflik karena keinginannya menjadi dewasa dan berdiri sendiri dan keinginan akan perasaan aman sebagai seorang anak remaja dalam keluarganya.

i. Banyak mengalami tekanan mental dan emosi. Terjerat dalam pesta hura-hura ganja, putau, ekstasi, dan pil-pil setan lain.

Terdapat banyak sebab remaja melakukan pergaulan bebas. Penyebab tiap remaja mungkin berbeda tetapi semuanya berakar dari penyebab utama yaitu kurangnya pegangan hidup remaja dalam hal keyakinan/agama dan ketidakstabilan emosi remaja. Hal tersebut menyebabkan perilaku yang tidak terkendali, seperti pergaulan bebas \& penggunaan narkoba yang berujung kepada penyakit seperti HIV $\&$ AIDS ataupun kematian. Berikut ini di antara penyebab maraknya pergaulan bebas di Kalangan remaja :

a. Sikap mental yang tidak sehat

Sikap mental yang tidak sehat membuat banyaknya remaja merasa bangga terhadap pergaulan yang sebenarnya merupakan pergaulan yang tidak sepantasnya, tetapi mereka tidak memahami karena daya pemahaman yang lemah. Dimana 
ketidakstabilan emosi yang dipacu dengan penganiayaan emosi seperti pembentukan kepribadian yang tidak sewajarnya dikarenakan tindakan keluarga ataupun orang tua yang menolak, acuh tak acuh, menghukum, mengolok-olok, memaksakan kehendak, dan mengajarkan yang salah tanpa dibekali dasar keimanan yang kuat bagi anak remaja, yang nantinya akan membuat mereka merasa tidak nyaman dengan hidup yang mereka biasa jalani sehingga pelarian dari hal tersebut adalah hal berdampak negatif, contohnya dengan adanya pergaulan bebas

b. Pelampiasan rasa kecewa

Ketika seorang remaja mengalami tekanan dikarenakan kekecewaannya terhadap orang tua yang bersifat otoriter ataupun terlalu membebaskan, sekolah yang memberikan tekanan terus menerus(baik dari segi prestasi untuk remaja yang sering gagal maupun dikarenakan peraturan yang terlalu mengikat), lingkungan masyarakat yang memberikan masalah dalam sosialisasi, sehingga menjadikan remaja sangat labil dalam mengatur emosi, dan mudah terpengaruh oleh hal-hal negatif di sekelilingnya, terutama pergaulan bebas dikarenakan rasa tidak nyaman dalam lingkungan hidupnya.

c. Kegagalan remaja menyerap norma

Hal ini disebabkan karena norma-norma yang ada sudah tergeser oleh modernisasi yang sebenarnya adalah westernisasi. Ini semua bisa terjadi karena adanya faktor-faktor kenakalan remaja berikut:

- Kurangnya kasih sayang orang tua.

- Kurangnya pengawasan dari orang tua.

- Pergaulan dengan teman yang tidak sebaya.

- Peran dari perkembangan iptek yang berdampak negatif.

- Tidak adanya bimbingan kepribadian dari sekolah.

- Dasar-dasar agama yang kurang. 
- Tidak adanya media penyalur bakat dan hobinya

- Kebebasan yang berlebihan

- Masalah yang dipendam.

Dampak yang ditimbulkan Pergaulan Bebas yang mana identik sekali dengan yang namanya "dugem" (dunia gemerlap). Yang sudah menjadi rahasia umum bahwa di dalamnya marak sekali pemakaian narkoba. Ini identik sekali dengan adanya seks bebas. Yang akhirnya berujung kepada HIV/AIDS. Dan pastinya setelah terkena virus ini kehidupan remaja akan menjadi sangat timpang dari segala segi.

Faktor-faktor yang menyebabkan remaja melakukan pergaulan bebas yang mengarah kepada prilaku menyimpang menurut Rizki Dwi Hartono dan Nur Dyah Gyanawati disebabkan oleh dua faktor yakni Faktor internal dan Faktor eksternal ${ }^{3}$

a. Faktor Internal

Faktor internal merupakan faktor yang muncul karena adanya dorongan dan kemauan dari individu itu sendiri. Pribadi manusia dapat dipengaruhi oleh sesuatu, karena itu ada usaha untuk membentuk pribadi, membentuk watak atau mendidik watak seseorang. Sejak dahulu diketahui bahwa pribadi tiap individu tumbuh atas dua kekuatan, yaitu kekuatan dari dalam, yang sudah dibawanya sejak lahir atau bisa disebut juga dengan kemampuan dasar dan kemampuan dari luar, yang diterima dan dipelajari individu dari keadaan sekitarnya dia berada. Pada tulisan ini ada dua hal yang secara internal ditemukan dalam mempengaruhi perilaku seksual remaja, diantaranya:

1) Aspek Perkembangan Alat Seksual (Biologis)

Perkembangan alat seksual (biologis) merupakan salah satu bentuk ciri-ciri perubahan pada remaja yang nampak dari luar,

${ }^{3}$ http://repository.unej.ac.id/bitstream/handle/123456789/58735/Riz ki\%20Dwi\%20Hartono.pdf?sequence=1, 29 November 2017 
sehingga secara langsung perubahan yang terjadi dapat dilihat oleh orang lain. Dari hal tersebut tentunya akan memiliki dampak apabila remaja yang mengalami perubahan pada fisiknya atau alat seksualnya (biologis) yang tidak terkontrol dengan baik. Hal ini dapat memancing pemikiran negatif seseorang terhadap remaja yang menyalahgunakan perubahan pada alat seksualnya (biologis). Dengan adanya perubahan alat seksual yang terjadi pada remaja perempuan mengakibatkan adanya pemikiran negatif bagi sebagian remaja laki-laki. Perubahan yang terjadi pada alat seksual remaja perempuan merupakan sebagai sarana untuk melakukan hubungan seks, sehingga penilaian mereka kepada remaja perempuan hanya sebatas alat pemuas nafsu. Remaja yang demikian ini tidak akan mampu menjalin hubungan yang serius dengan perempuan, karena pemikiran mereka terhadap perempuan hanya didasari oleh nafsu, bukan perasaan. Hal ini sesuai dengan pendapat Purwoko yang menjelaskan bahwa penyebab remaja berperilaku menyimpang yaitu salah satu dikarenakan adanya kualitas dari pribadi remaja itu sendiri, seperti perkembangan emosional yang kurang, adanya hambatan dalam perkembangan hati nurani dan ketidakmampuan dalam mempergunakan waktu luang sehingga lebih memilih kegiatan alternatif yang keliru dan hal tersebut dijadikan dalam kehidupan sehari-hari. ${ }^{4}$

2) Aspek Motivasi

Masa remaja merupakan masa dimana seorang anak remaja mulai dihadapkan pada realita kehidupan. Pada saat inilah jiwa seoarang remaja mengalami peralihan dari jiwa kekanak remaja-kanak remajaan kearah pendewasaan. Dalam masa

${ }^{4}$ Dian Rahmawati, Kontrol Sosial Masyarakat terhadap Perilaku Seks Pranikah Mahasiswa di RumahKost(Jember: Universitas Jember, 2012), h. 26 
peralihan ini tentunya anak remaja banyak mengalami peristiwa baru yang selama ini belum pernah dialami pada masa sebelumnya. Peralihan keadaan inilah yang dapat memicu timbulnya dorongan untuk mencoba hal-hal baru yang selama ini belum pernah mereka coba, tentunya tanpa pemikiran yang matang tentang akibat-akibat yang bisa ditimbulkan karena keterbatasan pemikiran pada usia dewasa. Sarwono yang menjelaskan bahwa motivasi adalah dorongan bertindak untuk memuaskan suatu kebutuhan, dorongan dalam motivasi diwujudkan dalam bentuk tindakan. ${ }^{5}$ Terdapat anggapan bahwa melakukan hubungan seks dengan tujuan untuk menjaga keutuhan hubungan yang telah mereka jalin bersama dengan pasangan masing-masing. Anggapan bahwa dengan melakukan seks dapat menjaga keutuhan hubungan merupakan hal yang keliru.. Keadaan tersebut sesuai dengan pendapat Darmasih yang menjelaskan bahwa apabila orangorang yang terlibat saling mencintai ataupun saling terikat menganggap bahwa hubungan seks sebelum menikah dianggap "benar". 6

b. Faktor Eksternal

Faktor eksternal merupakan faktor yang datang dari luar individu, yang dapat mendorong remaja untuk melakukan seks bebas. Diantaranya $^{7}$ :

1) Aspek Keluarga

Di dalam keluarga jelas dibutuhkan adanya komunikasi terutama orang tua dengan anak remaja-anak remajanya, karena hal

\footnotetext{
${ }^{5}$ Ririn Darmasih, Faktor yang Mempengaruhi Perilaku Seks Pranikah pada Remaja SMA di Surakarta(Surakarta: Universitas Muhammadiyah Surakarta, 2009), h.13

${ }^{6}$ Ibid., h. 32

${ }^{7}$ http://repository.unej.ac.id/bitstream/handle/123456789/58735/Riz ki\%20Dwi\%20Hartono.pdf?sequence=1, 29 November 2017
} 
tersebut dapat memberikan kehangatan dan hubungan yang baik antara orang tua dan anak remaja. Dengan adanya komunikasi, orang tua dapat memahami kemauan dan harapan anak remaja, demikian pula sebaliknya. Sehingga akan tercipta adanya saling pengertian dan akan sangat membantu di dalam memecahkan atau mencari jalan keluar dari persoalan yang dihadapi anak remajanya. Komunikasi merupakan hal yang penting dalam keluarga, karena dengan komunikasi dalam suatu keluarga terlihat adanya interaksi, hubungan yang akrab antar keluarga.Berbeda halnya ketika seorang anak remaja berada pada keluarga yang kurang adanya komunikasi antara orang tua dengan anak remaja. Hal ini dapat mengakibatkan anak remaja akan merasa kesepian di dalam keluarga. Kartono yang menjelaskan bahwa keluarga memiliki pengaruh yang luar biasa besarnya dalam pembentukan watak dan kepribadian anak remaja. ${ }^{8}$ Hal tersebut sesuai dengan pendapat Taris dan Senim yang berpendapat bahwa remaja yang tidak memiliki hubungan erat dan pengawasan dengan orang tua cenderung terlibat dalam hubungan seksual pranikah ${ }^{9}$.

2) Aspek Pergaulan

Bagi remaja seorang teman merupakan suatu kebutuhan, sehingga terkadang teman dianggap sebagai "orang tua kedua" bagi remaja. Dorongan untuk memiliki teman dan membentuk suatu kelompok juga dapat dipandang sebagai usaha agar tidak tergantung dengan orang yang lebih dewasa atau sebagai tindakan nyata dalam interaksi sosial. Maka didalam lingkungan pergaulan remaja selalu kita temukan adanya kelompok teman

${ }^{8}$ Kartini Kartono, Psikologi Abnormal (Bandung: CV. Mandar Madju, 1988), h. 286.

${ }^{9}$ Cyntia Puspitasari, T. Sikap Remaja Terhadap Hubungan Seksual Pranikah Ditinjau Dari Keterbukaan Dengan Orang Tua(Semarang: Universitas Katolik Soegijapranata, 2012), h. 41 
sebaya. Pergaulan dengan teman sebaya dapat membawa seseorang kearah positif dan negatif. Aspek positifnya adalah tersedianya saluran aspirasi, kreasi, pematangan kemampuan, potensi dan kebutuhan lain sebagai output pendidikan orang tua dan potensinya. Akan tetapi jika yang dimasukinya adalah lingkungan yang buruk maka akan mendorong mereka kepada hal negatif. Pergaulan dengan teman sebaya yang di dalamnya terdapat keakraban dan adanya intensitas pertemuan yang tinggi dapat memberikan pengaruh terhadap individu lain di dalam kelompok tersebut. A. Islami menjelaksan bahwa dengan adanya ikatan secara emosional dalam kehidupan peer group akan mendapatkan berbagai manfaat dan pengaruh yang besar bagi individu yang berada dalam kelompok tersebut. ${ }^{10}$ Misalnya timbul rasa penasaran dan keinginan untuk mencoba kebiasaan yang dilakukan oleh salah satu individu dalam kelompok tersebut. Hal tersebut akan berdampak positif ketika individu di dalam kelompok pergaulan meniru kebiasaan yang dilakukan oleh salah satu teman kelompoknya yang melakukan perbuatan positif. Berbeda halnya ketika individu tersebut meniru perbuatan yang negatif dari salah satu teman di dalam kelompoknya, maka kemungkinan besar individu tersebut akan meniru perbuatan negatif dari temannya. Hal ini sesuai dengan pendapat Adamassasmita yang menjelaskan bahwa remaja yang terlibat dengan tingkah laku delinquent akan mengarah kepada tingkah laku delinquent yang dibawa oleh teman-teman sebayanya. Keadaan ini disebabkan karena tingkat keakraban yang dekat dan intensitas pertemuan yang tinggi. ${ }^{11}$

10 Alam IslamiMahbub, M., Faktor-Faktor Eksternal Yang Menyebabkan Siswa SMA Bermain Game Online Beserta DampakDampaknya(Jember: Universitas Jember, 2012), h. 22-23.

${ }^{11}$ Ibid, h. 69 


\section{3) Aspek Media Massa}

Dampak yang ditimbulkan oleh media massa bisa beraneka ragam diantaranya, misalnya terjadinya perilaku yang menyimpang dari norma-norma sosial atau nilai-nilai budaya yang ada. Pengaruh media massa baik televisi, majalah, handphone dan internet sering kali di salah gunakan oleh kaum remaja dalam berperilaku sehari-hari, misalnyasaja remaja yang sering melihat tontonan kebudayaan barat, mereka melihat perilaku seks itu menyenangkan dan dapat diterima dilingkungannya. Kemudian dari hal tersebutlah kaum remaja mulai mengimitasikan pada pola kehidupan mereka sehari-hari. Kedua informan pokok perempuan memiliki kebiasaan menonton film barat yang di dalamnya di isi oleh adeganadegan seks yang menurut mereka hal tersebut merupakan suatu hal yang romantis. Dari anggapan tersebutlah sehingga terdapat paradigma bahwa adegan seks dalam romansa cinta merupakan suatu hal yang romantis. Adanya dorongan dan motivasi dari film barat yang mereka tonton bersama menimbulkan tindakan untuk mencotoh apa yang telah mereka anggap sebagai perwujudan rasa romantis dalam mengungkapkan cinta dan sayang kepada pasangannya. Hal tersebut sesuai dengan pendapat Jones yang menjelaskan bahwa media massa seperti film, musik, bacaan dan televisi telah mengajarkan kepada mereka bahwa seks itu romantis, merangsang dan menggairahkan. ${ }^{12}$

\section{Dampak Negatif Pergaulan bebas}

Pergaulan bebas yang menyimpang pada norma akan memberikan dampak negatif antara lain pada kesehatan, psikis dan masyarakat.

\footnotetext{
${ }^{12}$ Ibid, h. 210.
} 


\section{a. Dampak bagi kesehatan}

Menurut Dr. A. Kosasih dari bagian ilmu penyakit kulit kelamin FKUI yang dikutip oleh Burhanuddin Latief jenis penyakit yang disebabkan hubungan seksual (sexualy transmitted) sebagai berikut:

1) Peradangan ureta yang tidak spesifik (non espesific uretritus)

2) Kencing nanah

3) Kutil alat genital (condiloma accuninata)

4) Jamur kondidah pada alat genital (candidosis genetalis)

5) Herpes Alat Genital

6) Sifilis

7) Trichomonisasis

8) Bobo Kelenjar Limfe Inguinal. ${ }^{13}$

Hal yang sama pula dikemukakan oleh Fathi Yakin:

1) Penyakit Sipilis (Raja Singa)

Sipilis merupakan sejenis penyakit yang ditimbulkan oleh kuman, penyakit ini juga dikenal dengan nama raja singa. Biasanya cara menularnya berlangsung melalui hubungan seks yang diharamkan.

2) Gonorrho (Kencing Nanah)

Walaupun penyakit ini relatif tidak berbahaya kalau dibandingkan dengan sipilis namun ia sangat ditakuti penyebab penyakit ini adalah hubungan seks yang tidak legal. $^{14}$

Dr. Marwali Harahap mengatakan ada 14 penyakit seksual yang disebabkan oleh hubungan seks:

1) Sifilis ( Raja Singa )

\footnotetext{
${ }^{13}$ Burhanuddin Latief, Sekitar Penyakit Menular Seksual, Pedoman Rakyat, No. 27, 28 Maret 1996, h. 3

${ }^{14}$ Fatthi Yakin, Islam dan Seks (Cet. III. Jakarta, Cv. Firdaus, 1991), h. 46-47
} 
Penyakit ini disebabkan oleh Treponema Pallidium. Penularan penyakit ini disebabkan oleh senggama dan keduanya disebabkan oleh infeksi yang sama.

2) Gonore.

Ialah penyakit kelamin, yang pada pria permulaannya keluar nanah dari orifisum Uretra eksterna dan pada wanita biasanya tanpa gejala, hanya nanah keluar dari introitus vagina. Kuman penyebabnya ialah Neisseria Genorrhoeae.

3) Nonspesifik.

Adalah penyakit yang ditularkan melalui hubungan kelamin. Meskipun gejalanya tidak seberat uretritis genore, namun karena prevalensinya tinggi atau cenderungmeningkat di samping menyebabkan tekanan "Psiko Seksual" bagi penderitanya.

4) Herpes Genitalis.

Penyakit ini disebabkan oleh herpessimpleks Virus (HSV).

Penularannya akibat seks orogenital atau penularan melalui tangan.

5) Reiter

Beberapa penulis melaporkan bahwa penyakit reiter ada hubungannya dengan penyakit yang ditulari secara hubungan kelamin, terutama didaratan Inggris dan Amerika Utara. Sedangkan di Eropa, Asia dan Afrika Utara penyakit reiter lebih banyak ditemukan pada penderita disentri amuba, disentri disentri basilus, ataupun penderita diare nonspesifik..

6) Kondiloma Akuminata.

Insiden penyakit ini ditularkan melalui hubungan kelamin . Penyebab penyakit ini adalah Virus golongan paposa.

7) Moloskum Kantagiosum.

Penyakit kulit ini bersipat menular, berpindah dari satu satu orang ke orang lain. Penularan dapat terjadi dengan cara 
kontak langsung, melalui barang-barang yang dipakai, Misalnya handuk atau autoinokulasi.

8) Kandidiasis Genitalis.

Penyakit ini melalui hubungan kelamin karena itu digolongkan juga dalam penyakit yang ditularkan melaluihubungan kelamin. Dikemikakan bahwa hal ni merupakan penyebat terpenting terjadinya kandidiasis oral pada bayi.

9) Trikomoniasis.

Suatu penyakit yang disebabkan infeksi parasit ( Trichomonas Vaginalitas) yang biasanya ditularkan secara hubungan kelamin dan menyerang bagian bawah trakus urogenitalis baik pria maupu wanita.

10) Ulkus Molle.

Adalah penyakit yang ditularkan melalui hubungan seksual pada orang genitalia. Penyebabnya adalah kuman Haemophillus ducreyi.

11) Limfogranuloma Venerum.

Adalah penyakit peradangan pada sistem saluran pembuluh limfe dan kelengjar limfe

12) Granuloma Inguinale.

Penularan penyakit ini biasanya melalui kontak langsung atau alat-alat tidur.

13) Pedikulosis.

Merupakan penyakit menular dan ditimbulkan oleh infestasi parasit (paddiculus/ phthirus atau kutu ). Penyakit ini ditularkan melalui hubungan kelamin (Seksually Transmitted Diseases). ${ }^{15}$

15 Marwali Harahap, Penyakit Menular Seksual (Cet. 2. Pt.Gramedia, Jakarta, 1990) h. 13-159. 
Menurut Aisyah, dampak yang ditimbulkan dari pergaulan bebas terhadap kesehatan di antaranya ${ }^{16}$ :

a. Adanya dampak Fisik bagi wanita yang di bawah usia 17 tahun yang pernah melakukan hubungan seks bebas akan beresiko tinggi terkena kanker serviks.

b. Beresiko tertular penyakit kelamin dan HIV-AIDS yang biasa menyebabkan kemandulan bahkan kematian.

c. Terjadinya KTD (Kehamilan yang Tidak Diinginkan) hingga tindakan aborsi yang dapat menyebabkan gangguan kesuburan, kanker rahim, cacat permanen bahkan berujung pada kematian.

b. Dampak Psikis

Persisifisme pergaulan bebas di kalangan remaja dewasa ini, memunculkan

proses perubahan orientasi dan sudut pandang terhadap fenomena kehidupan itu sendiri. Pergaulan tanpa batas yang dari sudut pendidikan Islam jelas-jelas tidak bisa dibenarkan walau ditinjau dari sudut manapun sekedar untuk melihat kebenarannya.Pergaulan bebas di kalangan remaja baik pada lakilaki dan terlebih lagi pada remaja putri, bukan hanya merendahkan martabatnya sebagai wanita, tetapi juga menjual masa depannya dengan harga murah. Pola pikir instan ketidak patuhan pada pola tuntunan agama, dangkalnya pemahaman terhadap pesan moral budaya bangsa menjadikan pelakunya kehilangan masa depan. ${ }^{17}$

Tidak bisa dinafikan lagi, gambaran kelam fenomena pergaulan bebas tersebut memunculkan konsekuensi psikologis

${ }^{16}$ Aisyah, Dampak Negatif Pergaulan BebasTerhadap Generasi Muda Menurut Tinjauan Pendidikan Islam, Skripsi (UIN Alauddin Makassar, 2013), h. 32

${ }^{17}$ Abu Al-Gifarri, Romantika Remaja, Kisah-kisah Tragis dan Solusinya dalam Islam(Bandung, Mujahid Press, 2002), h.124. 
dan resiko-resiko kejiwaan yang sulit diobati dengan terapi tehknologi kesehatan. Di antara konsekuensi psikologi tersebut adalah sebagai berikut:

1) Pergeseran pandangan remaja modern terhadap seks

Pergaulan bebas, seks di luar nikah, kumpul kebo dan semacamnya sudah menjadi tradisi yang tidak asing lagi disaksikan melalui pemberitaan media massa. Pacaran bahkan dijadikan ukuran untuk melihat kesetiaan dengan kesediaan untuk mencurahkan kasih tanpa batas di luar nikah. Pandangan remaja terhadap nilai kesucian dan keperawananpun mulai bergeser. ${ }^{18}$

Sebagai konsekuensi rill adalah munculnya sipat sulit mempercayai orang lain di sekelilingnya. Perasaan berdosa, benci pada diri sendiri, perasaan tidak berharga dan beragam beban psikis lainnya pada gilirannya nanti akan membawa trauma berkepanjangan pada pelakunya.

2) Pergaulan bebas dan perilaku seks yang eksplosif.

Dapat memicu individu berprilaku menyimpang seksual untuk memuaskan keinginan-keinginan di luar batas kewajaran.

3) Pergaulan bebas adalah awal dari kesesatan selanjutnya.

Biang kesesatan yang umum terjadi di kalangan remaja sekarang ini adalah munculnya budaya pacaran yang menjadi biang keladi kemungkaran. Pacaran pada umumnya melegalkan hubungan mesra antara lawan jenis sebelum jenjang pernikahan.

Umumnya generasi muda tidak menyadari bahwa pacaran yang dijalaninya adalah sebuah jalan yang menghantarkannya pada aib, kerusakan moral dan harga diri yang tergadaikan. Dengan setia mempersembahkan

${ }^{18}$ Ibid, h.129 
kehidupannya pada nafsu serakah yang menjadikannya sebagai sosok binatang yang bertubuh manusia. Kenyataan ini menjadikan manusia yang berprilaku demikian diatas berada dalam kondisi psikis yang labil, tidak merasakan nikmat kepuasan batin yang sempurna, serta kosong jiwanya dari cahaya Ilahi.

Dampak Psikologis yang seringkali terlupakan ketika melakukan free seks atau mengalami dampak fisik akibat free seks diatas adalah akan selalu muncul rasa bersalah, marah, sedih, menyesal, malu, kesepian, tidak punya bantuan, bingung, stress, benci pada diri sendiri, benci pada orang yang terlibat, takut tidak jelas, insomnia (sulit tidur), kehilangan percaya diri, gangguan makan, kehilangankonsentrasi, depresi, berduka, tidak bisa memaafkan diri sendiri, takut akan hukuman Tuhan, mimpi buruk, merasa hampa, halusinasi, sulit mempertahankan hubungan.

Secara psikologis seks pra nikah memberikan dampak hilangnya harga diri, perasaan dihantui dosa, perasaan takut hamil, lemahnya ikatan kedua belah pihak yang menyebabkan kegagalan setelah menikah, serta penghinaan terhadap masyarakat. Maka pengendalian hawa nafsu sebagai jihad terbesar sepanjang hidup dengan kepatuhan dan keimanan pada ajaran agama. Dengan hal ini dapat mencegah hubungan terlalu jauh sebelum nikah. Bagi yang tidak mampu mengendalikan hawa nafsu seyogyanya melaksanakan pernikahan dengan dasar kesiapan dari kedua pasangan secara kepribadian, kematangan mental, emosional, sosial dan fisik serta sikap mengedepankan rasa tanggung jawab. Dan tak lupa syarat pernikahan ini haruslah berdasar perasaan saling cinta-mencintai dan harga-menghargai. 
Sudah semestinya generasi muda menghindari budaya berpacaran yang mana pacaran merupakan budaya asing yang belepotan syahwat dan birahi. Bahkan ketika cinta itu tumbuh semakin dewasa, syahwat dan birahi tidak lagi menjadi tujuan yang memiliki arti. Dalam bentuknya yang dewasa itu, cinta lebih kentara dengan wujud kepasrahan, keikhlasan, dan peneguhan eksistensi.

c. Dampak bagi Masyarakat

Di satu segi masalah seks sangat bebas seperti di kalangan orang-orangmaterialistis. Dan disegi lain dibatasi semaksil mungkin, seperti di kalangan orang-orang sufi yang ekstrim. Akan tetapi, Islam mempunyai posisi tersendiri dalam mengaturnya. Tujuan dari pengaturan ini ialah untuk menjamin kestabilan masyarakat dari kerusakan-kerusakan yang ditimbulkan oleh penyimpangan-penyimpangan dalam masalah seks. Jika kita mempelajari atau membaca lembaranlembaran sejarah tentang keadaan berbagai bangsa di masa lampau yang mengalami kehancuran, maka kita akan mengetahui bahwa kehancuran itu disebabkan oleh kebebasan seks.

Fathi Yakin mengatakan dampak negatif yang ditimbulkan oleh pergaulan bebas bagi masyarakat, ada empat yaitu $^{19}$ :

a. Seks dapat merongrong kekayaan rakyat.

Keserakahan seks dan keonaran dalam suatu masyarakat, Secara spontan dibarengi oleh tersebarnya kemewahan, kemubaziran dan penghamburan kekayaan, yang mempunyai dampak sangat jelek terhadap masyarakat. Sebab rakyat kehilangan sumber daya yang seyogyanya bisa dimamfaatkan di sektor-sektor lain, seperi industri pertanian

\footnotetext{
${ }^{19}$ Fathi Yakin, op.cit., h. 69-72
} 
dan pembangunan, serta hal-hal yang dapat menunjang kemajuan dan kemakmuran.

b. Seks mempengaruhi kesehatan umum.

Bila kebebasan seks diiringi dengan menghamburhamburkan kekayaan melanda suatu bangsa, maka hal itu mengakibatkan dampak negatif terhadap masyarakat, dimana mereka akan ditimpa berbagai penyakit dan penderitaan. Seorang Dokter Prancis mengungkapkan bahwa setiap tahun di Prancis tiga puluh ribu orang meninggal dunia akibat penyakit sipilis.

c. Seks Dapat Merusak Hubungan Masyarakat.

Di antara dampak negatif dari kebebasan seks adalah hancurnya keluarga dan rusaknya kesatuan masyarakat, serta putusnyan hubungan silaturahmi.

d. Seks Dapat Melunturkan Akhlak.

Di antara fenomena keruntuhan akhlak akibat kebebasan seks, adalahmenonjolnya tabiat hewani pada seseorang, menyebarnya sifat masa bodoh tanpa batas.

Menelaah pendapat di atas dapat dikonklusikan bahwa efek pergaulan bebas tidak hanya berbahaya bagi para remaja akan tetapi berdampak negatif bagi kemaslahatan seluruh ummat manusia.

Pengalaman sejarah telah membuktikan betapa besarnya harta kekayaan untukmerongrong masyarakat menghamburhamburkan harta kekayaannya untuk memenuhi kebutuhan seksualnya dengan cara ilegal. Kekayaannya terkuras dipergunakan untuk perbuatan yang tidak bermanfaat, akhlak menjadi rusak dan hubungan antara sesama manusia serta hubungan dengan Tuhan akan terputus. Dengan demikian mereka akan ditimpa dengan berbagai macam penyakit yang membahayakan seperti penyakit AIDS, sipilis serta penyakit kelamin lainnya. Sehingga mereka dihantui dengan ketakutan, 
yang disebabkan perbuatan mereka sendiri, maka dengan demikian mereka sendirilah yang mengeksekusi diri mereka.

C.Peranan pendidikan dalam menghindari pergaulan bebas anak usia remaja

Perkembangan merupakan pola gerakan dinamis yang dijalani manusia. Dari sejak perkembangan pra-natal, proses pendidikan sudah dimulai. Para psikolog perkembangan yang mengasumsikan bahwa perubahan yang terjadi diasumsikan untuk mencapai sesuatu yang lebih baik dan menghasilkan perilaku yang adaptif, lebih terorganisasi, lebih efektif, dan lebih kompleks ${ }^{20}$.

Sebagai landasan perkembangan selanjutnya, perkembangan awal merupakan pondasi penting bagi terbentuknya berbagai aspek perkembangan yang mencakup fisik, intelektual, emosi, sosial, dan moral pada masa selanjutnya. Dari berbagai kajian literatur, perkembangan fisik berhubungan dengan perubahan pada fungsi tubuh, perkembangan intelektual mencakup perkembangan kognitif dan bahasa yang berkaitan dengan proses berfikir. Sementara perkembangan emosi mengacu pada perkembangan yang berkaitan dengan emosi dasar manusia yang dirasa dan diekspresikan, sedangkan perkembangan sosial-moral berhubungan dengan berbagai perubahan berbagai cara anak remaja ketika berhadapan dengan lingkungan sosial dan berbagai aturan serta tata krama yang ada.

Selain adanya berbagai aspek perkembangan pada diri anak, ada satu hal penting yang perlu disadari bahwa semua anak menjalani kehidupannya melewati berbagai tahapan perkembangan. Masingmasing tahapan perkembangan tersebut memiliki karakteristik yang khas. Dari tahap perkembangan pra-natal, bayi, kanak-kanak, remaja, dewasa, dan usia lanjut mencerminkan serangkaian proses

${ }^{20}$ Berk, L. E., Development Through Lifespan: Dari Prenatal Sampai Remaja (edisi kelima), (Yogyakarta: Pustaka Pelajar, 2012), h. 54. 
perkembangan yang bertautan satu dengan yang lain. Faktor penting yang menunjang perkembangan yang optimal dari setiap tahapan perkembangan yang dijalani anak remaja dalam menghindari pergaulan bebas adalah keberhasilan dari setiap proses pendidikan dan pengasuhan yang didapatkannya, baik melalui pendidikan formal di suatu lembaga ataupun dari lingkungan di sekitar anak remaja.

Proses pendidikan diartikan sebagai usaha yang dilakukan anak remaja ataupun lembaga untuk mengembangkan dan menfasilitasi berbagai potensi manusia. Sementara, pengasuhan merupakan aktivitas yang dilakukan orangtua, pendidik, dan lingkungan terdekat anak remaja dalam dimensi penerimaan dan kontrol terhadap anak remaja tersebut. Dalam keterkaitan dengan hubungan orangtua atau pendidik dan anak remaja, penerimaaan menggambarkan bagaimana orang tua dan pendidik menghargai, menanggapi (responsif) dan menghukum bila anak remaja berperilaku salah, serta menunjukkan afek positif, sedangkan kontrol merujuk pada gambaran bagaimana orang tua dan pendidik membatasi perilaku, menuntut, membimbing, serta melindungi anak remaja.

Seiring dengan perkembangan usia, pendidikan dan pengasuhan yang diterima anak remaja harus sesuai dengan usia yang diikuti dengan berbagai kebutuhan yang berbeda pula. Dalam hal ini, lingkungan yang memberikan pendidikan dan pengasuhan harus memahami betul bagaimana strategi atau metode pembelajaran dan pendekatan yang tepat, baik secara anak remaja maupun klasikal. Bila sesuai dengan apa yang dibutuhkan anak remaja jiwa yang sehat akan tumbuh. Karena itu faktor utama yang mempengaruhi kesehatan mental anak remaja adalah bagaimana lingkungan terdekat anak remaja tersebut memberikan kekuatan psikologis yang dapat mengggali dan mengembangkan berbagai potensi yang dimilikinya.

Salah satu isu penting pendidikan yang sering dikaji dari berbagai sudut pandang adalah pembentukan karakter pada anak 
remaja. Karakter merupakan wadah dari berbagai karakteristik psikologis yang membimbing anak remajauntuk dapat menyesuaikan diri dengan variasi lingkungan yang dihadapi serta untuk menghindari pergaulan bebas. Dengan kata lain karakter akan "memimpin" diri untuk mengerjakan sesuatu yang benar dan tidak mengerjakan sesuatu yang tidak benar ${ }^{21}$ Karakter inilah menjadi penentu apakah anak remaja mampu atau tidak menyesuaikan diri dengan keanekaragaman situasi yang dihadapinya terutama untuk mengindari pergaulan bebas.

Hal ini terlihat dalam cara berperilaku anak remaja yang merupakan akumulasi dari berbagai pembentukan aspek diri yang baik. Bila dilihat dari sudut pandang Psikologi Perkembangan, tentu saja karakter yang terbentuk bukanlah sesuatu yang tiba-tiba ada, namun merupakan hasil dari proses perjalanan hidup anak remaja yang terbentuk dari kematangan biologis maupun perkembangan psikologisnya. Kematangan mengacu pada perubahan-perubahan yang terjadi secara alamiah dan spontan, sementara itu, perubahan yang terkait perkembangan psikologis terkait dengan pengalaman belajar yang didapatkan dari lingkungan sekitarnya. Oleh karena itu, satu hal yang perlu diperhatikan adalah bagaimana proses pendidikan dan pengasuhan yang didapatkan anak remaja, sehingga membentuk pengalaman belajar yang bermakna bagi dirinya yang dapat digunakan untuk menghindari pergaulan bebas.

Pendidikan yang menstimulasi perkembangan karakter anak remaja pada intinya berisi tentang kajian yang berkenaan dengan norma dan nilai yang bermuara pada pembentukan moral. Lingkungan terdekat anak remaja, orangtua dan pendidik, mensosialisasikan norma dan nilai dalam berbagi konteks dan cara. Lebih lanjut dijelaskan bahwa setiap aktivitas pengasuhan dan

${ }^{21}$ Berkowitz, M. W.,The science of character education. In Damon, W. Bridging in a New Era in Character Education, (Hoover Institution Press, 2002), h. 78. 
pendidikan yang berorientasi kepada anak remaja hendaknya bermuatan aktivitas belajar yang tidak hanya melibatkan aspek kognitif saja, melainkan juga melibatkan aspek afektif, serta sosial dan moral.

Berkenaan dengan pembentukan karakter anak remaja, ada lima hal yang dipertanyakan sebagai dasar untuk mengevaluasi proses pendidikan yang diterima anak remaja ${ }^{22}$, yaitu:

1. Bagaimana lingkungan memperlakukan anak remaja?

Pemaknaan dan pemahaman yang baik tentang diri dan lingkungan didapatkan anak remaja dari seberapa besar ia dapatkan dari lingkungannya. Dalam social cognitive theory ${ }^{23}$, anak remaja mempelajari perilaku tidak melalui coba (trial) dan salah (error), namun dengan melihat perilaku orang lain atau model. Pada pengkajian berkenaan dengan pemecahan masalah sosial dapat dijelaskan bahwa perilaku anak remaja terbentuk dari hasil pengamatan yang melibatkan peran aktif kognitif. Dalam hal ini lingkungan yang diamati adalah perilaku orangtua, pendidik, dan masyarakat dalam aktivitas pengasuhan dan pendidikan yang diberikan kepada anak remaja. Mengajarkan pada anak remaja bagaimana menggunakan pemecahan masalah yang tepat seperti mengajarkan tentang apa permasalahannya, berpikir tentang berbagai strategi pemecahan, mempertimbangkan tentang apa yang mungkin terjadi, memberikan alternatif solusi, dan mengevaluasi solusi yang dipilih, akan membantu anak remaja belajar tentang berbagai konsekuensi perilaku. Hal itu juga menguatkan kemampuan anak remaja dalam berpikir mengenai berbagai alternatif strategi pemecahan masalah.

\footnotetext{
${ }^{22}$ Ibid

${ }^{23}$ Bandura, A. Social foundations of thought and action: A social cognition theory(New Jersey : Prentice Hall, Inc, 1986), h.96.
} 
2. Bagaimana lingkungan terdekat (orang tua dan pendidik) memperlakukan orang lain ketika anak remaja berada pada situasi tersebut?

Salah satu cara manusia belajar adalah melalui pengamatan atau observasi. Hasil belajar tersebut tidak selalu direfleksikan dalam bentuk tindakan saat itu juga. Walaupun tidak langsung tertuju ke anak remaja, namun anak remaja sebagai anak remaja aktif terus merekam apa yang terjadi pada lingkungannya. Sesuatu yang dipelajari dalam satu waktu mungkin akan direfleksikan dalam bentuk perilaku dalam waktu yang lain. Hal ini dapat diartikan bahwa hasil belajar anak remaja dari lingkungan dapat saja tidak langsung terlihat, akan tetapi sangat dimungkinkan muncul dalam tahapan perkembangan selanjutnya. Konsekuensi terhadap perilaku tersebut berperan penting dalam belajar. Ketika perilaku yang diamati mendapat konsekuensi yang baik dan menyenangkan bagi model, maka anak remaja cenderung untuk menirunya. Begitupun sebaliknya, bila perilaku yang diamati tersebut tidak mendapatkan konsekuensi yang positif, maka cenderung tidak ditiru. Konsekuensi yang didapatkan model ini dapat bersifat eksternal, yaitu seseorang mengatakan atau memberi sesuatu atas perilaku model terhadap dirinya. Selain itu juga dapat bersifat internal yang ditunjukkan dengan respon kepuasan pada diri model.

3. Apakah ada harapan untuk membentuk karakter yang baik pada anak remaja dan lingkungannya, baik di dalam keluarga maupun di lembaga pendidikan?

Nilai atau norma yang ditanamkan kepada anak remaja harus jelas dan dipahaminya. Selain itu juga menekankan apa arti penting dari nilai atau norma tersebut bagi diri dan lingkungannya. Segala aktivitas pengasuhan, baik di rumah, di lembaga pendidikan, maupun di masyarakat diharapkan memiliki kesamaan tujuan besar, sedangkan tujuan kecil disesuaikan 
dengan kondisi yang dihadapi. Adanya harapan tersebut akan mengarahkan perilaku. Hal ini dikuatkan oleh Albert Bandura bahwa harapan merupakan variabel penting dalam pengubahan lingkungan maupun perilaku. Suasana yang kondusif dan konsisten yang berlaku untuk semua, akan mempercepat terwujudnya harapan tersebut. ${ }^{24}$ Hal ini dikarenakan anak remaja memahami setiap langkahnya dan terhindar dari kebingungan aturan.

4. Apakah anak remaja diberi kesempatan untuk mempraktikkan karakter yang baik?

Belajar menguasai kemampuan tertentu membutuhkan berbagai kesempatan bagi anak remaja untuk mempraktekkan kemampuan tersebut dengan dukungan dan bimbingan. Orangtua dan pendidik memberikan atmosfer yang kondusif, sehingga anak remaja dapat bebas mengekspresikan pemikiran kritis dan sesuatu yang dipikirkan ataupun dirasakan. Komunikasi terbuka dan diskusi tentang isu-isu tertentu akkan membuka wawasan dan perilaku yang lebih bijak dalam menghadapi sesuatu. Melalui pembiasaan, perilaku adaptif akan muncul spontan ketika anak remaja menemukan kejadian sesuatu yang harus dihadapi.

5. Apakah ada kerjasama antara orangtua dan pihak lembaga pendidikan?

Pentingnya peranan orangtua dalam pendidikan anak remaja telah disadari banyak pihak sebagai salah satu pilar keberhasilan pendidikan anak remaja. Berbagai hasil penelitian menunjukkan bahwa bila orangtua berperan terhadap pendidikan anak remaja di lembaga pendidikan, maka dampak-dampak positif yang dirasakan, yaitu :

${ }^{24}$ Santrock, J. W.,Life-span Vevelopment, diterjemahkn oleh Achmad Chusairi, S.Psi \& Drs. Juda Damanik, M.S.W., dengan judul Perkembangan Masa Hidup(Jakarta : Penerbit Erlangga, 2006), h. 85 
a. Adanya kesuksesan anak remaja beradaptasi di sekolah, ditandai dengan adanya prestasi yang diraih atau mudahnya penguasaan dasar-dasar bidang akademik.

b. Sangat berkaitan dengan peningkatan harga diri anak remaja, berkurangnya permasalahan perilaku serta meningkatkan motivasi untuk menjalankan program kegiatan belajar

c. Bagi pihak lembaga pendidikan, terjalinnya kerjasama dengan orangtua akan membawa kemudahan pendidik dalam menentukan strategi yang benar dalam menghadapi anak remaja serta memunculkan perlakuan yang konsisten antara orangtua dan pihak pendidik

Siapa sajakah yang Menjadi Sumber Pembentukan Karakter Anakusia remaja?

\section{Pertama, keluarga.}

Faktor keluarga diyakini sebagai faktor yang paling utama berpengaruh pada anak usia remaja. Melalui aktivitas pengasuhan yang terlihat dari cara yang dipilih orangtua dalam mendidik anak, anak remaja akan tumbuh dan berkembang dari pengalaman yang didapatnya. Studi-studi menemukan bahwa hubungan yang hangat dan saling mendukung dalam keluarga berhubungan dengan pembentukan karakter yang positif pada anak usia remaja. Sebaliknya hubungan antara orangtua dan anakusia remaja yang penuh dengan konflik dan sikap kekerasan berhubungan dengan kemunculan masalah-masalah psikologis pada masa selanjutnya. Pemecahan masalah sosial merupakan bagian dari kompetensi sosial sebagai hasil dari interaksi yang kompleks antara anak remaja dan lingkungan. Peran dan keteladanan orangtua, aktivitas pengasuhan, dan interaksi sehari-hari mengajarkan arah dari strategi pemecahan masalah sosial. Lebih lanjut dijelaskan bahwa hubungan antara anak remaja dan orangtua atau pendidik yang menimbulkan rasa aman yang digambarkan anak merasa dirinya layak dan berharga 
diprediksikan akan mempengaruhi bagaimana anak mengatasi masalah yang menekan ataupun masalah sehari-hari dengan cara yang positif. Pada intinya, bagi orangtua maupun pendidik, hubungan dengan anak remaja diharapkan adanya keterbukaan, suportif, penuh kasih sayang, saling menghargai, serta konsisten ${ }^{25}$.

Kedudukan orang tua yakni ibu dan bapak peranannya sangat strategis dalam membina dan mengembangkan potensipotensi yang ada pada diri setiap anak-anaknya, sebelum anak-anak itu memasuki atau melanjutkan kejenjang pendidikan formal. Di samping itu pula ia juga sebagai motivator untuk mengarahkan anakanaknya agar dalam berbuat dan bertindak beorientasi kepada sipat yang konstruktif,penuh kebahagiaan terlepas dari tindakan dan perbuatan yang dstruktif. Keluarga yang baik akan berpengaruh positif bagi perkembangan anak, sedangkan keluarga yang jelek akan berpengaruh negatif. ${ }^{26}$

Dengan demikian dapat dipahami bahwa kedudukan orang tua juga berpengaruh pada tingkah laku anak-anaknya. Apa yang diperbuat oleh orang tuanya pasti akan diikuti oleh anak-anaknya pula. Situasi keluarga sangat berpengaruh terhadap pertumbuhan. kepribadian seorang anak. Suami dan istri yang hidup rukun atau yang selalu cekcok dalam rumah tangga yang dilihat dan didengar anaksetiap hari, pasti mempengaruhi seluruh kehidupannya.

Free seks yang terjadi di kalangan remaja tidak terlepas dari faktor keluarga. Keadaan orang tua yang kurang memperhatikan anak-anaknya dalam kehidupannya sehari-hari yang disebabkan salah satu di antara komponen keluarga tersebut terlalu sibuk sehingga tidak dapat memberikan pendidikan kepada anak-anaknya. Dalam kaitan ini Bimo Walgito yang dikutib oleh Sudarsono bahwa tidak jarang orang tua tidak dapat bertemu dengan anak-anaknya. Coba

${ }^{25}$ Berkowitz, op.cit., h. 75.

${ }^{26}$ Sudarsono, Kenakalan Remaja (Cet. II, Jakarta: PT. Rineka Cipta 1991), h.125. 
bayangkan orang tua kembali dari kerja, anak-anak sudah bermain di luar, anak pulang orang tua sudah pergi lagi, orang tua datang anakanak sudah tidur, dan seterusnya. Keadaan yang semacam ini jelas tidak menguntungkan perkembangan anak. Dalam situasi keluarga yang demikian anak mudah mengalami frustasi, mengalami komplikkomplik psikologis. $^{27}$

Berdasarkan beberapa pendapat di atas dapat disimpulkan bahwa tindakan orang para tua dalam hal ini bapak dan ibu yang jarang bertemu dengan anak-anaknya akan memberikan peluang maksimal terhadap anak-anaknya untuk senantiasa berberintegrasi dengan lingkungan di mana anak tersbut berada.

Pengalaman-pengalaman yang diperoleh anak apakah itu pengalaman baikataukah pengalaman buruk akan senantiasa berpengaruh terhadap psikisnya. Sehingga anak tersebut mencari jalan keluar untuk memecahkan masalahnya dengan sendiri, apakah hasil analisis itu baik atau tidak, itu tidak pernah dipikirkan. Baginya yang penting problema dapat teratasi sekalipun bertentangan dengan ajaran agama dan nilai-nilai moral serta budaya masyarakat. Maka tidak mengherankan dalam keluarga seperti ini memberikan peluang kepada remaja untuk berbuat melakukan pergaulan bebas dalam bentuk seks bebas di luar nikah.

Pada dasarnya pergaulan bebas yang terjadi di kalangan para remaja yang

disebabkan oleh faktor keluarga ini, juga disebabkan oleh ketidak harmonisan hubungan suami istri dalam membina keluarga sakinah, yang menyebabkan broken home. Kenyataan menunjukkan bahwa anak-anak yang melakukan kejahatan disebabkan karena di dalam keluarga terjadi disentigrasi.

Dengan demikian orang tua dalam hal ini ibu dan bapak yang tidak pernah

\section{${ }^{27}$ Ibid}


memberikan perhatian ataukah membiarkan anak-anaknya begitu saja dalam berinteraksi dengan suasana lingkungan yang tidak menguntungkan berpengaruh

buruk terhadap perkembangan jiwa anak. Sehubungan dengan pembahasan di atas

Henri N. Siahaan berpendapat bahwa apabila dalam suatu keluarga ayah dan ibu sibuk dengan urusan masing-masing, maka pengawasan dan pengadilan terhadap anak-anak sudah pasti berkurang. Anakanak akan terlalu bebas melakukan apa saja yang diinginkan tanpa ada larangan atau petunjuk yang kongkrit dari orang tuaSituasi rumah tangga yang demikian mempunyai peluang besar untuk menghasilkan anak-anak nakal. ${ }^{28}$

Hal yang sama pula di kemukakan oleh Marawali Harahap bahwa tidak

disilinnya pengawasan orang tua dapat mempengaruhi agama terhadap para remaja bertambah longgar. Anak mudah lebih cepat matang dari semula dan berhasrat berdikari pada umur yang lebih muda. Kesempatan bergaul bebas pada masing-masing jenis menjadi lebih muda pada waktu itu. ${ }^{29}$

Jika disimpulkan kedua pendapat di atas dapat dipahami bahwa minimnya

perhatian orang tua terhadap anaknya akan berpengaruh terhadap perkembangan

tingkah laku anak. Dalam hal ini peluang untuk melakukan pergaulan bebas lebih

besar. Seluruh kegagalan di kalangan remaja membuktikan bahwa, dimasa kanak-

\footnotetext{
${ }^{28}$ Henry N. Siahaan,Pembinaan Anak dala Keluarga (Cet. II; Jakarta: PT. Rineka Cipta 1991), h. 31

${ }^{29}$ Marwali Harahap, Penyakit menular Seksual (Cet.II;Pt. Gramedia Jakarta, 1990), h. 4
} 
kanak mereka tidak bisa menyusuaikan dirinya dan bekerja sama dalam kehidupan keluarganya. Manaster dan Corsini berpendapat, yang dikutip Mauricie Balson mengatakan bahwa setiap kenakalan dimulai dari rumah. Anak-anak hanya berbuatmenyerang orang lain jika sudah terlatih untuk bersikap menyerang didalam keluarganya. Orang tua yang bertindak kasar atau tak ambil peduli, di luar sadarnya,telah menjadikan remaja nakal melalui metode yang salah arah. Bersikap sebagaiorang tua baik,adalah jalan pemecahan yang utama yang kita anjurkan untuk melawan kenakalan remaja. ${ }^{30}$

\section{Kedua, Institusi Prasekolah (pendidik).}

Bagaimana iklim kelas yang mendukung perkembangan potensi anak remaja? Institusi pendidikan prasekolah merupakan tempat anak-anak belajar mengembangkan berbagai macam aspek perkembangan yang ada pada dirinya, yang salah satunya adalah mengembangkan kemandirian. Perlu disadari bahwa hasil yang diharapkan dari institusi prasekolah bagi anak-anak adalah tidak sekedar menyediakan tempat bermain. Satu hal yang juga diharapkan adalah proses internalisasi nilai yang menuju kepada kemampuan mengurus dirinya sendiri (self-help skill) atau yang dikenal dengan istilah kemampuan otonomi.Sejalan dengan ciri khas periode ini sebagai sebuah masa bermain, hampir seluruh kegiatan pada usia prasekolah perlu melibatkan unsur bermain. Melalui kegiatan bemain anak belajar mengembangkan kemampuan untuk mengolah diri dan teman bermain dalam konteks interaksi sosial. Dalam proses pembelajaran di insitusi prasekolah, yang harus dilakukan pendidik adalah memberikan lingkungan dan stimulasi yang cocok untuk memenuhi kebutuhan anak didik sesuai dengan karakteristik perkembangannya. Walaupun anak memiliki keunikan

${ }^{30}$ Maurice Balson, Menjadi orang tua Yang Baik (Cet. I, Bumi Aksara, Jakarta, 1993)h. 144 
masing-masing disertai latar belakang yang berbeda, pendidik perlu memberikan metode pembelajaran yang variatif, sehingga suasana belajar menjadi "hidup". Hal ini juga untuk menfasilitasi setiap perbedaan yang ada pada anak. Dengan landasan pemikiran tersebut pendidik harus mendasarkan diri pada suatu pedoman pendidikan yang tepat untuk anak didik.

\section{Ketiga, teman sebaya.}

Melalui interaksi sosial, anak akan belajar berbagi, bergantian, mengendalikan dan menyelesaikan konflik, serta menjaga dan mempertahankan hubungan. Pada anak usia dini,semakin banyak berinteraksi sosial, maka hubungan timbal balik akan terjadi sehingga secara psikologis kemampuan sosialisasi semakin terasah. Interaksi teman sebaya merupakan pusat sosialisasi pada masa kanak-kanak. Interaksi ini menambah kemahiran kompetensi sosial dan kompetensi yang bersifat komunikasi yang tidak seperti kontribusi yang diperoleh dari interaksi dengan orang dewasa. mengatakan bahwa ada beberapa manfaat yang akan didapatkan anak-anak dari hasil pertemanan dengan teman sebaya, yaitu ; mengembangkan pertumbuhan kompetensi sosial, memberikan sumber dorongan ego, memberikan keamanan emosional yang mengancam situasi, memberikan sumber keintiman dan kasih sayang, memberikan bimbingan dan bantuan, serta memberikan kesempatan mempelajari arti pertemanan dan pemberian motivasi.

Dalam konteks berinteraksi dengan teman sebaya, anak dapat memperoleh kesempatan untuk menguji adanya perbedaan ide, belajar untuk bernegosiasi dan mendiskusikan sudut pandang yang banyak, serta untuk memutuskan berkompromi atau menolak gagasan dari teman sebaya. Pengalaman interaksi dengan teman sebaya ini diyakini menghasilkan perkembangan yang positif dan adaptif untuk anak, seperti kemampuan memahami pemikiran, emosi dan tujuan orang lain. 


\section{Keempat, Kepatuhan terhadap Agama.}

Kepatuhan dalam beragama akan mentransmisikan nilai nilai diprediksikan efektif. Sebagai pihak pengontrol, taat beragama dapat berperan aktif untuk mendukung pihak orangtua, pendidik, dan masyarakat dalam pengembangan perilaku anak usia remaja. Nilainilai moral dalam beragama ditekankan untuk dijalani sebagai pedoman untuk dapat menyesuaikan diri dalam berbagai konteks. Hal ini dimaksudkan agar anak usia remaja mengerti tentang arti penting nilai-nilai yang dianutnya bagi kehidupan maupun lingkungan sosialnya.

Anak usia remaja harus diberi pemahaman bahwa Islam menganggap seks sebagai sesuatu hal yang suci, fitrah, dan bahkan sebagai sarana untuk mendekatkan diri pada Allah swt.. Dalam suatu hadist dikatakan, " Dua rakaat shalat yang didirikan oleh orang yang kawin lebih baikdaripada keterjagaan (ibadah) di malahm hari dan puasa (disiang hari) orang yang tidak kawin." Namun seks yang bagaimana? Tentu saja seks yang sesuai denganaturan-aturan syariat Islam, seks yang "memanusiakan" manusia bukan seks ala hewanyang dapat merendahkan derajat kita sebagai manusia. Allah swt menciptakan naluri seks pada diri manusia sebagai sarana penjaga kesinambungan eksistensi umat manusia di dunia dan juga sebagai sarana kesenangan bagi manusia. Firman Allah SWT dalam al-Qur'an ar-Rum (30):21

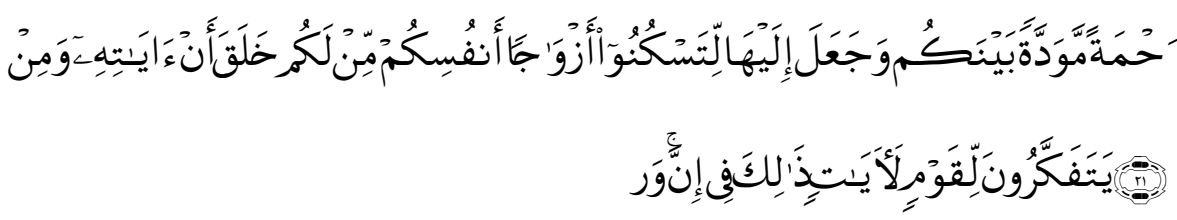

Terjemahnya : dan di antara tanda-tanda kekuasaan-Nya ialah Dia menciptakan untukmu isteri-isteri dari jenismu sendiri, supaya kamu cenderung dan merasa tenteram 
kepadanya, dan dijadikan-Nya diantaramu rasa kasih dan sayang. Sesungguhnya pada yang demikian itu benar-benar terdapat tanda-tanda bagi kaum yang berfikir. $^{31}$

Allah swt. menciptakan hasrat seksual (syahwat) pada manusia. Syahwat

sama normalnya dengan nafsu makan dan minum. Seperti hasrathasrat lain yangAllah ciptakan pada manusia, hasrat seksual sangatlah kuat dan dapat menguasai

manusia yang lemah. Allah SWT berfirman dalam Al-Qur'an QS.Ali Imran (3): 14

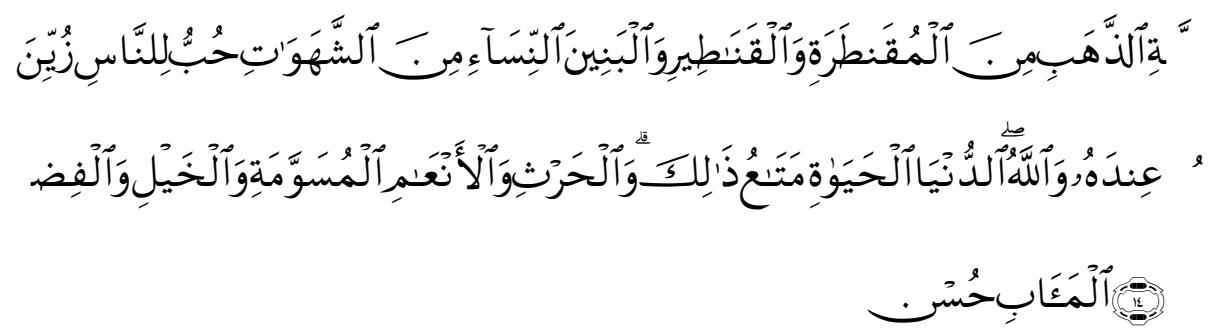

Terjemahnya :

Dijadikan indah pada (pandangan) manusia kecintaan kepada apa-apa yang diingini, Yaitu: wanita-wanita, anak-anak, harta yang banyak dari jenis emas, perak, kuda pilihan, binatangbinatang ternakdan sawah ladang. Itulah kesenangan hidup di dunia, dan di sisi Allah-lah tempat kembali yang baik (surga).

Hasrat seksual, sebagaimana nafsu makan dan minum, dapat dipenuhi dengan cara yang halal maupun yang haram. Adalah haram untuk memuaskan hasrat seksual di luar ikatan perkawinan, sesama jenis, dengan hewan ataupun dengan orang mati (mayat). Islam

${ }^{31}$ Departemen Agama RI, al-Qur'an dan Terjemahannya (Jakarta: PT. Bumi Restu, 1994), h. 712 
melarang penolakan dan penekanan menyeluruh terhadap naluri seksual. Rasulullah SAW melarang para sahabatnya mengebiri diri mereka sendiri agar mereka dapat tekun beribadah sepanjang waktu.

Seks bukan suatu kata yang "kotor", seks adalah anugrah Allah swt kepada

umat manusia. Islam menyediakan sarana-sarana dan aturan-aturan yang halal untuk menikmati anugrah Ilahi ini. Seks bukan hanya sarana reproduksi, tetapi juga sarana dalam memperoleh kesenangan dan kenikmatan. Bahkan jika seks dipraktekkan dalam kerangka yang benar sesuai dengan syariat Islam bukan hanya kesenangan dan kepuasan yang didapat melainkan juga pahala dari Allah swt.. Perkawinan atau pernikahan adalah satu-satunya sarana yang sah, halal, bagi pemenuhan kebutuhan seksual dan reproduksi. Rasulullah SAW bersabda "Wahai sekalian pemuda, siapa di antara kalian yang telah mempunyai kemampuan (untukmenikah) maka menikahlah. Sesungguhnya pernikahan itu lebih dapat menjagapandangan mata dan mengekang hawa nafsu. Bagi siapa yang belum memiliki kemampuan, maka berpuasalah. Sesungguhnya puasa adalah penawar baginya" (HR Bukhari). Memenuhi kebutuhan seksual di luar ikatan perkawinan adalah dosa. Tinggal terserah pada manusia sendiri apakah mau mengikuti petunjuk-Nya ataukah tidak. Allah SWT berfirman dalam al-Qur'an surah al-Ahzab (33): 36

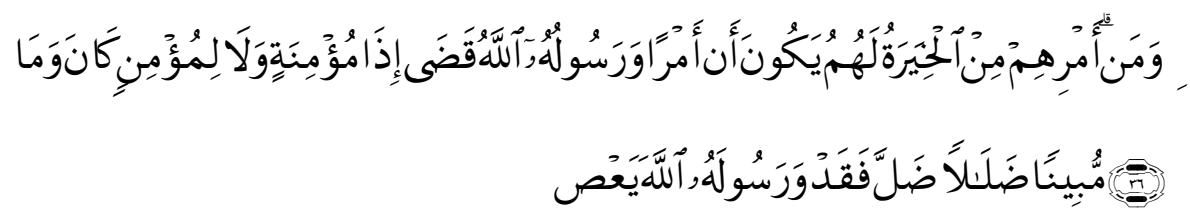

Terjemahnya :

Dan tidaklah patut bagi laki-laki yang mukmin dan tidak (pula) bagi perempuan yang mukmin, apabila Allah dan Rasul-Nya telah menetapkan suatu ketetapan, akan ada bagi mereka pilihan (yang lain) tentang urusan mereka. dan 
Barangsiapa mendurhakai Allah dan Rasul-Nya Maka sungguhlah Dia telah sesat, sesat yang nyata.

Dalam masyarakat masa kini interaksi antara laki-laki dan wanita yang bukan

muhrim sulit dihindari. Kedua jenis kelamin dalam penampilan dan tingkah lakunya dapat merangsang nafsu seksual. Hal ini dapat menggiring kepada perbuatan dosa (zina). Dalam Islam bukan hanya perzinahan yang harus dihindari, segala sesuatu yang mendekati (berpotensi) menggiring kepada perzinahan juga harus dihindari. Hukuman berat menanti para pelaku perzinahan. Allah SWT berfirman: "Dan janganlah kamu mendekati zina, sesungguhnya zina itu adalah suatu perbuatan yang keji, dan suatu jalan yang buruk" (QS Al-Israa': 32). Di ayat lain Allah swt. berfirman:'Perempuan yang berzina dan laki-laki yang berzina, maka deralah tiap-tiap seorang dari keduanya seratus kali dera, dan janganlah belas kasihan kepada keduanya mencegah kamu untuk (menjalankan) agama Allah, jika kamu beriman kepada Allah dan hari akhirat dan hendaklah (pelaksanaan) hukuman mereka disaksikan oleh sekumpulan dari orang-orang yang beriman. Laki-laki yang berzina tidak mengawini melainkan perempuan yang berzina atau perempuan musyrik danperempuan yang berzina tidak dikawini melainkan oleh laki-laki yang berzina atau laki-laki musyrik dan yang demikian itu diharamkan atas orang-orang Mukmin"

Untuk mengatasi pandangan yang salah dan memberii penjelasan yang benar tentang seks serta untuk mengatasi seks bebas diperlukan adanya pendidikan agama kepada anak usia remaja tentang seks yang ilmiah, benar, tepat, bertanggung jawab dan dilandasi nilai-nilai serta aturan agama. Hal yang perlu diberikan meliputi konsep tentang seks ditinjau dari aspek Islam dan medis, pengenalan organ-organ seks, kesehatan reproduksi, proses 
kehamilan dan melahirkan, bahaya seks bebas dan cara penanggulangannya serta aturan-aturan Islam yang mengaturnya.

Dalam syariat Islam, setiap perbutan yang diharamkan Allah SWT, selalu

memiliki latar belakang yang mengarah kepada tindak kejahatan yang menimbulkan kerugian pada manusia itu sendiri setiap perbuatan yang membahayakan jiwa manusia selalu diharamkan. Dan lantaran itulah, setiap muslim diperintahkan untuk berusaha menjauhi hal-hal tersebut, guna melindungi dirinya dan masyarakat.

Sehubungan dengan penjelasan tersebut bahwa pergaulan bebas para generasi muda tentunya mendapat ancaman dari Allah swt, karena perbuatan tersebut adalah perbuatan yang tercela yang diharamkan Allah swt. Ancaman Allah ini telah dijelaskan dalam alQur'an Al-Isra' (17): 32.

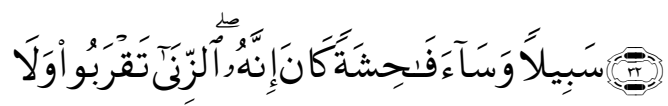

Terjemahnya : dan janganlah kamu mendekati zina; Sesungguhnya zina itu adalah suatu perbuatan yang keji. dan suatu jalan yang buruk.

Anak usia remaja harus diberikan pemahaman bahwa: Hukum zina ada tiga macam yakni hukum dera (di cambuk), diasingkan, dan dirajam (di lempar batu sampai mati). Bila mereka yang berzina itu belum kawin, maka hukumannya di dera dan di asingkan. Hal ini berdasarkan firman Allah dalam surat An-Nur (24):2 yang berbunyi:

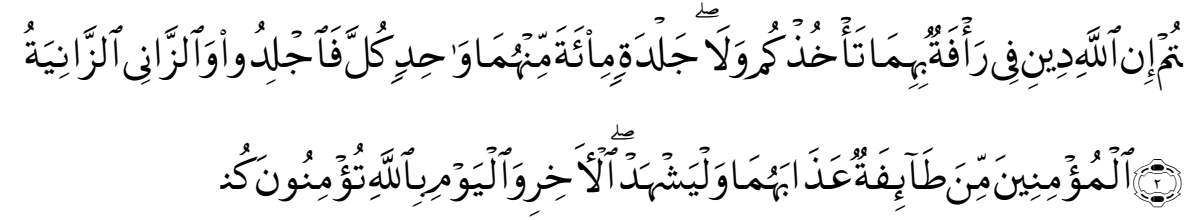

Terjemahnya 
Perempuan yang berzina dan laki-laki yang berzina, Maka deralah tiap-tiap seorang dari keduanya seratus dali dera, dan janganlah belas kasihan kepada keduanya mencegah kamu untuk (menjalankan) agama Allah, jika kamu beriman kepada Allah, dan hari akhirat, dan hendaklah (pelaksanaan) hukuman mereka disaksikan oleh sekumpulan orang-orang yang beriman.

Dari penjelasan firman Allah di atas dapat dipahami bahwa dampak negatif daripada pergaulan bebas atau zina tidak hanya berakibtakan buruk untuk keselamatan akhirat akan tetapi berakibat buruk bagi keselamatan hidup di dunia.

\section{Kelima, Komunitas.}

Komunitas tidak saja berarti masyarakat saja yang berperan dalam pembentukan perilaku, tetapi juga termasuk eksposur media. Melalui Berbagai penelitian telah menunjukkan bahwa media berperan dalam pembentukan perilaku agresif pada anak-anak. Sebagai pengendali, orangtua dan pendidik harus bersikap kritis terhadap tayangan-tayangan yang merusak moral anak. Mengkritisi setiap tayangan yang ditonton, akan membentuk berfikir kritis pada anak. Secara berproses, bila pengertian terus diberikan, maka anak akan menyeleksi sendiri tontonan apa yang baik untuk dirinya.

Berhubungan dengan kondisi lingkungan masyarakat yang mempengaruhi

terbentuknya pergaulan bebas di kalangan generasi muda. Maka kecenderungan

perubahan masyarakat menuju destruktif nilai perlu diladeni anak agar remaja tidak secara spontan mengadopsi etika lingkungan yang membentuknya menjadi jauh dari tuntunan agama. Anak remaja sebagai anggota masyarakat selalu mendapat pengaruh dari keadaan masyarakat dan lingkungannya baik langsung maupun tidak 
langsung. Pengaruh yang dominan adalah akselerasi perubahan sosial yang ditandai dengan peristiwa-peristiwa yang sering menimbulkan ketegangan seperti persaingan dalam perekonomian, pengangguran , media massa, dan fasilitas hiburan lainnya.

Menurut Abu Ahmadi, Lingkungan dapat memberikan pengaruh yang positif maupun pengaruh yang negatif terhadap jiwanya, dalam sikapnya, dalam ahklaknya, maupun dalam perasaan agamanya. $^{32}$

Menganalisis ke dua konteks asumsi tersebut di atas dapat dipahami bahwa

perubahan-perubahan sosial dalam masyarakat, yang menuntut masyarakat untuk

meningkatkan taraf kehidupannya sehingga terjadi persaingan dalam segala aspek.Hal yang demikian tentunya akan berpengaruh pada pola kehidupan dalam bermasyarakat. Bagi masyarakat yang hidup di bawa garis kemiskinan juga berusaha dengan semaksimal mungkin untuk mendapatkan kehidupan yang layak. Guna memenuhi tuntutan kebutuhan hidup anggota keluarganya. Pada dasarnya kondisi ekonomi global memiliki hubungan yang erat dengan timbulnya kejahatan. Di dalam kehidupan sosial adanya kekayaan dan kemiskinann mengakibatkan bahaya besar bagi jiwa manusia di dalam hidupnya termasuk anak-anak remaja.

Pendapat di atas sangat mendasar jika dikaitkan dengan kenakalan remaja

khususnya terjadinya pergaulan bebas di kalangan generasi muda. Rangsangan-

rangsangan yang diterima dari lingkungan dimana anak muda itu berada sangat

${ }^{32}$ Abu Ahmadi, Metode Khusus pendidikan Agama (Bandung, Armico, 1996), h.51 
berpengaruh terhadap tingkah lakunya. Keinginan untuk menyamakan diri dengan

golongan-golongan orang yang memiliki tingkat kehidupan yang lebih atau kaya

senantiasa mendominasi pemikirannya, sehingga remaja tersebut berusaha untuk

mendapatkan kehidupan yang selaras dengan kawan-kawannya atau anggota masyarakat lainnya, sekalipun usaha yang dilakukannya melanggar hukum, seperti porstitusi dan profesi wanita yang mengarah kepada pergaulan bebas di luar nikah.

Selain pendididikan yang fokus pada pembentukan karakter juga sangat diperlukan pendidikan berbasis gender untuk mengantisipasi anak usia remaja pada pergaulan bebas.

Pendidikan berbasis gender jangan diterjemahkan sebagai upaya perempuan melawan laki-laki. Bukan demikian. Namun, bagaimana perempuan dapat mendapatkan kesetaraan nonkodrati. Yang dalam jangka panjang dapat meningkatkan perlindungan, pelayanan dan kesejahteraan kaum perempuan yang rentan sebagai pihak yang paling dirugikan dalam pergaulan bebas pada anak usia remaja.

Dimana Secara hukum, perempuan dan laki-laki memiliki hak, kesempatan, dan kewajiban yang sama untuk mendapatkan pendidikan. Prestasi perempuan dalam dunia pendidikan masih dipandang rendah dibandingkan dengan kaum laki-laki. Hal itu menjadikan kaum perempuan belum memiliki ruang dalam menyalurkan aspirasi-aspirasinya karena keterbatasan akses yang diirikan oleh masyarakat yang melegitimasi perbedaan peran dan kedudukan antara laki-laki dan perempuan. Apalagi dalam sebagian masyarakat kita berasumsi bahwa secara alamiah laki-laki diciptakan dengan kelebihan-kelebihan yang tidak didapat pada kaum perempuan. Anggapan semacam ini disebabkan oleh faktor-faktor kultural masyarakat paternalistik yang cenderung memposisikan 
perempuan sebagai second gender; masyarakat kelas dua.Oleh karena itu dengan terwujudnya pendidikan berbasis gender, perempuan tidak lagi menjadi korban perilaku pergaulan bebas.

\section{KESIMPULAN}

Salah satu tujuan pendidikan adalah pembentukan karakter pada anak usia remaja. Karakter merupakan wadah dari berbagai karakteristik psikologis yang membimbing anak remaja untuk dapat menyesuaikan diri dengan variasi lingkungan yang dihadapi serta untuk menghindari pergaulan bebas. Dengan kata lain karakter akan "memimpin" diri untuk mengerjakan sesuatu yang benar dan tidak mengerjakan sesuatu yang tidak benar. Karakter inilah menjadi penentu apakah anak remaja mampu atau tidak menyesuaikan diri dengan keanekaragaman situasi yang dihadapinya terutama untuk mengindari pergaulan bebas. Selain itu dengan terwujudnya Pendidikan berbasis gender, perempuan dapat mendapatkan kesetaraan nonkodrati. Yang dalam jangka panjang dapat meningkatkan perlindungan, pelayanan dan kesejahteraan kaum perempuan yang rentan sebagai pihak yang paling dirugikan dalam pergaulan bebas pada anak usia remaja.

\section{DAFTAR PUSTAKA}

Abu Ahmadi, Metode Khusus pendidikan Agama,Bandung, Armico, 1996.

Abu Al-Gifarri, Romantika Remaja, Kisah-kisah Tragis dan Solusinya dalam Islam, Bandung, Mujahid Press, 2002.

Aisyah, Dampak Negatif Pergaulan BebasTerhadap Generasi Muda Menurut Tinjauan Pendidikan Islam, Skripsi, UIN Alauddin Makassar, 2013 
Alam Islami Mahbub, M., Faktor-Faktor Eksternal Yang Menyebabkan Siswa SMA Bermain Game Online Beserta Dampak-Dampaknya, Jember: Universitas Jember, 2012.

Bandura, A. Social foundations of thought and action: A social cognition theory New Jersey : Prentice Hall, Inc, 1986.

Berk, L. E., Development Through Lifespan: Dari Prenatal Sampai Remaja (edisi kelima), Yogyakarta: Pustaka Pelajar, 2012.

Berkowitz, M. W., The science of character education. In Damon, W. Bridging in a New Era in Character Education, Hoover Institution Press, 2002.

Burhanuddin Latief, Sekitar Penyakit Menular Seksual, Pedoman Rakyat, No. 27, 28 Maret 1996, h. 3

Cyntia Puspitasari, T. Sikap Remaja Terhadap Hubungan Seksual Pranikah Ditinjau Dari Keterbukaan Dengan Orang Tua, Semarang: Universitas Katolik Soegijapranata, 2012.

Departemen Agama RI, al-Qur'an dan Terjemahannya,Jakarta: PT. Bumi Restu, 1994.

Dian Rahmawati, Kontrol Sosial Masyarakat terhadap Perilaku Seks Pranikah Mahasiswa di RumahKost, Jember: Universitas Jember, 2012

Fatthi Yakin, Islam dan Seks,Cet. III. Jakarta, Cv. Firdaus, 1991.

Henry N. Siahaan, Pembinaan Anak dala Keluarga,Cet. II; Jakarta: PT. Rineka Cipta 1991.

http://repository.unej.ac.id/bitstream/handle/123456789/58735/Rizki \%20Dwi\%20Hartono.pdf?sequence $=1$, 29 November 2017

http://repository.unej.ac.id/bitstream/handle/123456789/58735/Rizki \%20Dwi\%20Hartono.pdf?sequence $=1$, 29 November 2017

Kartini Kartono, Psikologi Abnormal,Bandung: CV. Mandar Madju, 1988.

, Patologi social (PT. RajaGrafindo Persada:Jakarta, 2005), h.4 
Marwali Harahap, Penyakit Menular Seksual,Cet. 2. Pt.Gramedia, Jakarta, 1990.

Maurice Balson, Menjadi orang tua Yang Baik,Cet. I, Bumi Aksara, Jakarta, 1993.

Ririn Darmasih, Faktor yang Mempengaruhi Perilaku Seks Pranikah pada Remaja SMA di Surakarta, Surakarta: Universitas Muhammadiyah Surakarta, 2009.

Santrock, J. W., Life-span Vevelopment, diterjemahkn oleh Achmad Chusairi, S.Psi \& Drs. Juda Damanik, M.S.W., dengan judul Perkembangan Masa Hidup, Jakarta : Penerbit Erlangga, 2006

Sudarsono, Kenakalan Remaja, Cet. II, Jakarta: PT. Rineka Cipta 1991.

Yusuf Abdullah , Bahaya Pergaulan Bebas,Jakarta : Media Dakwah , 1990 